\title{
Teachers' Perceptions of Museum-Based Learning and Its Effects on Creativity: A Preliminary Study
}

\author{
Eni Puji Astuti ${ }^{1}{ }^{*}$ I Wayan Suardana $^{1}$, Dwi Retno Sri Ambarwati ${ }^{1}$, Dwi Wulandari ${ }^{1}$, \\ Badrul Isa ${ }^{2}$ \\ ${ }^{1}$ Faculty of Languages and Arts, Yogyakarta State University, Yogyakarta, Indonesia \\ ${ }^{2}$ Faculty of Education, Universiti Teknologi MARA \\ *Corresponding author. Email: enipa@uny.ac.id
}

\begin{abstract}
In the 21 st century, creativity is considered as one of the main assets for individuals to develop in such a sustainable way that encourages the education to develop creative pedagogical concepts. One of the learning environments created is an active-collaborative student learning strategy by utilizing various facilities outside the classroom including museums. By developing museum-based learning, it is assumed that the quality of learning outcomes to be achieved will be more optimal. The present study is on the results of preliminary research on museum-based learning in Indonesia and Malaysia. This study focuses on examining the perceptions of teachers in Indonesia towards museum-based learning and its effects on student creativity. The data were collected through surveys and interviews and analyzed in qualitative. The result of the research revealed that respondents had a positive perception of museum-based learning as it facilitates concrete fact-based learning, provides a new atmosphere in learning resulted in improvement of student motivation, facilitates learning in and through arts, and serves as a means of appreciation. According to the respondents, museumbased learning can affect both student and teacher creativity, especially in the aspects of insight and inspiration that generate new ideas and add the variety of solutions that students can come up with when solving a problem. However, teachers still experience various obstacles in carrying out museum-based learning both in terms of the availability of funds, infrastructure, human resources, permission, supporting curricula, and museum conditions.
\end{abstract}

Keywords: Museum-based learning, Creativity, Teacher perception

\section{INTRODUCTION}

Responding to changes in a civilization that are so fast and limitless, the focus of 21 st-century education is on the development of 4Cs: Communication, Collaboration, Critical Thinking, and Creativity. The last two points also lead to the development of the Higher Order Thinking Skill (HOTS) which includes analyzing, evaluating, and creating skills [2]. These competencies, especially creativity, are considered important because it is the main reasons for the next generation to develop sustainably (sustainable development) to face an unpredictable future. To face the challenges, experts and practitioners are encouraged to conduct research and construct concepts about creative pedagogy (eg [3], [7], [17], [20], [27], [31]). In short, creative pedagogy is characterized by the development of originality and creativity [16] through the design of imaginative and innovative curriculum, as well as learning strategies [19].

In creative pedagogy, creativity refers to the ability to respond to problems and offer solutions through new things in a divergent manner. It is considered a habit that can be inhibited or eliminated by certain educational curricula and practices [34], [8], [25], [9], [29]. Therefore, strategies to create a creative learning atmosphere and to build creative habits are important. In various studies, it is found that the atmosphere that encourages the growth of creativity, among others, is the existence of a balance between standard procedures and freedom which let the student have lees pressuring learning atmospheres, conduct experiments to solve problems, draft and criticize ideas, make use of various sources [18], actively participate in empowerment, and collaborate with various parties as peers teachers [12]. [6]. Moreover, they need to be provided with flexibility, 
spontaneity, and imagination [15], room for unpredictability, improvisation, and learning autonomy [30]. Other important points for building creative pedagogy mentioned by Davies et al. [18] are a collaboration with outside agencies and learning activities outside the classroom (working beyond the classroom). Museum-based learning is a strategy to make collaboration as well as to conduct learning outside classrooms. This learning strategy can provide a sufficiently flexible space for students to explore and synthesize various important information that will play a role in their creative process.

One of the main functions of a museum is for educational purposes. This means that museums need to have many collaborations with the community, especially educational institutions [26]. Museums need to be more innovative in approaching educational institutions, providing services, and working in accordance with the demand of the global era. Unfortunately, museums in Indonesia tend to be constantly conventional. There are various conditions that make the innovation of the museum programs do not run well. However, it is expected that there will be efforts to develop the museum into a living laboratory of innovation [33].

Art education and art-based learning have unique characteristics that may serve as a means of fostering creativity through learning activities that encourage students to always criticize pre-existing ideas and reject stereotypes [32],[35]. Furthermore, when art education and art-based learning are carried out in collaboration with museums, the learning outcomes may become more optimum as museum-based learning will optimize the multi-sensory involvement of students.

To develop creative pedagogy through museum-based learning in Indonesia and Malaysia, this research examines the perceptions of teachers in Indonesia towards museum-based learning and its effects on creativity.

\section{LITERATURE REVIEW}

Creativity is the ability to respond to problems and give solutions by offering new things in a divergent way. The new paradigm in the world of education considers creativity, not as a gift or innate talent but an ability that can be taught, nurtured, or stunted. Craft [14], [11], [13] in its 'little-c' concept states that creativity can appear in daily activities related to various domains of life. Everyone has creative abilities in various forms and birtlevels [21]. This allows education to explore the development of creativity through the concept of creative pedagogy. In creative pedagogy, various theories and concepts for the practical implementation of how to design curriculum and learning strategies are able to foster creative thinking and the ability to transform from "what is" to "what might be" [23].
Various studies reveal that the majority of factors forming creativity are internal aspects such as imagination. However, Chappel et al. [5] argue that what drives creativity is not only imagination but also other factors, one of which is the interaction of someone's ideas with other people's ideas or other things outside himself. This means that in the creative process, a person does not only need self-potential and moments of reflection or incubation of ideas, but also opportunities to see and interact with the surrounding environment so that ideas or inspiration comes up from these interactions. In response to this, conventional learning in a strict classroom is considered to limit the potential for creativity to develop. To encourage the development of student creativity, it is necessary to hold learning activities outside the classroom (working beyond the classroom), one of which is to go to museums. It means that a collaboration with the museum is also needed [18], [37]. Until recently, museums are only seen as a means of additional insight and appreciation, in creative pedagogy, museum-based learning is oriented to facilitate ideas or inspiration generation for work [10].

In line with the vision of creative pedagogy, museums can facilitate educational services, social interests, science and technology, culture, and tourism destination. Then, for educational purposes, a museum can be a place to develop talents and interests, creativity and innovation, and passion. In Indonesia, there is a law concerning museums, namely Law No.66/2019 [22]. It is stated in the law that the use of museums for educational services can be done in several ways, including by bringing students to museums, organizing mobile museums, and providing information on museums and collections. However, in practice, museum programs remain conventional so that the museum facilities and infrastructure are not optimally used [33]. To meet the demands of this era, it is necessary to carry out sustainable studies to develop museum management policies related to collections, programs, and human resources.

\subsection{Related Study}

One of the relevant studies is a project conducted by The Singapore Art Museum in collaboration with several schools [36] entitled Think Contemporary!. This program is a museum-based school program that facilitates learning through art. Based on a multidisciplinary approach, art in this program is used as a learning medium to foster students' critical thinking skills. One of the programs carried out is a museum visit that links the school curriculum with activities at the museum. Apart from that, various permanent gallery collections in the form of artworks are used as learning resources in the classroom. Unfortunately, this program only facilitates to use of museum collections as a medium of learning or learning through art because this 
program limits the possible positive impact of learning in, with, and about arts [24], [4].

Another relevant research is by Price and Chiu [1] on museum-based learning in the field of science and an urban context. As many as 1676 students from grades 4 to 8 and 125 teachers were involved in an experiment to measure the level of content understanding, changes in attitudes towards science, and teacher and student behavior in the classroom. The results of this study show that there is an increase in teachers' understanding of science material by $7 \%$ and students $4 \%$ (in answering multiple choice questions) and $11 \%$ (in answering essay questions) compared to the control class. For teachers, there is no change in attitudes towards science, but there are changes in teacher self-efficacy and teaching anxiety levels. Apart from this, it is found that museum-based learning in science learning leads to student-centered learning. This finding is in line with various experts stating that informal or outside-class learning environments such as museum-based learning can encourage student active-participation.

Focusing on the partnership aspect, research by Rahm [28] presents the importance of collaboration between schools, museums, and other parties that may be involved. Although this project is a collaboration between a school and a museum, this program involves archaeologists, artists, and scientists in learning activities. This research is sufficient to provide an overview of how to make learning that can involve students actively based on cross-setting learning. This research also highlights the importance of innovative learning that involves students as co-designer, so that students feel they are involved and motivated.

\subsection{Paper Structure}

The rest of the paper consists of Section 2 that presents the method used in collecting and analyzing data, Section 3 that presents the results, and Section 4 that concludes the study and presents possibilities for future research.

\section{RESEARCH METHOD}

To answer the research question related to Indonesian teachers' perceptions of museum-based learning and its effect on creativity, this study used a qualitative research method with a descriptive approach. The scope of research was information on how to use museums in learning, and creative aspects to be developed in museum-based art learning. The data were obtained through surveys and interviews. The research subjects were elementary, junior high, and senior high school teachers in Indonesia. There were 30 teachers who filled in the distributed questionnaires and five teachers who were willing to be interviewed. The collected data were analyzed by categorizing and looking for patterns of information.

\section{RESULT}

In this section, some important points are presented from the data analysis of the preliminary study. The section is expected to describe how teachers' perceptions of museum-based learning and how it influences creativity.

\subsection{Respondent Demography Profile}

Respondents of this preliminary study were 30 teachers from various regions in Indonesia. Of the thirty respondents, 18 were high school teachers, 7 were junior high school teachers, and 5 were elementary school level teachers. In detail, the data on the number of respondents and subjects being taught are as follows: 1 English teacher, 1 Javanese language teacher, 1 counseling teacher, 1 visual communication design teacher, 1 textile craft design and production teacher, 2 physics teachers, 4 classroom teachers, 1 science teacher, 1 social studies teacher, 1 chemistry teacher, 2 math teachers, 1 craft and entrepreneurship teacher, 10 teachers of Cultural Arts and Crafts, 1 history teacher, 1 TTQ (Tahsin and Tahfidz Quran) teacher, and 1 thematic teacher.

Of these 30 respondents, $50 \%$ or 15 people had used museums as a learning infrastructure. The museums that they visited are Popo Iskandar Museum, Art Space Museum, Bengkulu Museum, Ujungpandang Fort Rotterdam Museum, West Kalimantan Provincial Museum, Banten Museum, Danar Hadi Solo Batik Museum, Sonobudoyo Museum, Batik Museum, Lampung Museum, Education Museum Indonesia, Yogyakarta Palace Museum, Wayang Museum, Tembi Museum, Vederburg Fort Museum, Affandi Museum, and Suharto Museum

\subsection{Teacher Perception of Museum-Based Learning}

The following are teachers' opinions about Museum based learning

\subsubsection{Concrete Fact-based Learning}

According to respondents, museums were an important aspect of learning, especially those related to history. Through museum visits, students could see firsthand historical facts through the artifacts on display. By doing such a way, students might experience concrete learning. They were introduced to the history and invited to explore sources or artifacts. One respondent stated that the museum visit was a means to "explore qauniyah verses". Qauniyah means God's sentences which are not written or stated in holy books but rather be witnessed directly through facts, circumstances, or events. 
Learning experiences like this are important learning strategies so that students are able to observe directly and make the relation of the theories they learn in the classroom with the facts presented in the museum.

\subsubsection{New Atmosphere in Learning}

Some teachers argued that museums served the functions of educational tourism. The learning condition in a museum was different from that of conventional classes, thus providing unique experiences for the students. The students felt a new atmosphere in learning and had unusual learning experiences. Teachers who once invited students to visit the museum stated that student learning motivation increased in teaching-learning processes. Most students thought that a visit to a museum is more interesting than studying in class. Learning in a museum is an interesting experience for students, thus encouraging them to be open to new knowledge. This activity results in the easiness of accepting learning material.

\subsubsection{Learning in art}

When visiting museums with the theme of art and culture, students got to know and understand art more broadly. According to respondents, the museum was a source of learning or a place for field study. Museum is where we see firsthand artworks. One respondent mentioned that when he made a visit to the batik museum, he could find out about the history of batik and ancient or classic batik motifs. Other respondents stated that every student, whether he had a high artistic talent or not, had the right to get the knowledge of art. Therefore, museum-based learning is one strategy that can provide opportunities for all students to learn more about art.

\subsubsection{Learning through art}

Most teachers argued that visits to museums provided opportunities for students to learn through works of art. The museum has a collection of historical artifacts, most of which are visual cultural products such as furniture, sculptures, parts of traditional houses, traditional clothing, as well as other arts and crafts products. These artifacts can be used as learning media. Through these cultural heritage traces, students get an idea of what actually happened with civilization in the past. In other words, students can find out about the history of civilization through works of art.

\subsubsection{Appreciation}

Most teachers said that museum-based learning was closely related to the appreciation aspect. As many as $63.3 \%$ of the respondents stated that museum-based learning could improve students' competency in terms of appreciation, while $36.7 \%$ of respondents mentioned other aspects such as communication skills, reasoning, creation, and others play important roles in improving the competences. Through museum visits, students can see first-hand cultural artifacts and works of art. Thus, students can appreciate the cultural artifacts and works of well-known artists.

\subsection{Teacher Assumption of Improving Student Creativity through Museum-based Learning}

Regarding the impacts of museum-based learning on student creativity, $83.3 \%$ of the teachers thought that museum-based learning could improve student creativity. Only $3.3 \%$ (1 person) answered that there was no relationship between museum-based learning and student creativity, while $13.3 \%$ answered that there might be a relationship.

As many as $96.6 \%$ of teachers answered that there was and there probably was an influence of museum-based activity on student creativity. They presented several aspects of creativity that were considered to improve after conducting museum-based learning.

Some of the most frequently mentioned aspects are related to student capability of 1) generating many ideas, answers, and problem-solving; 2) exploring and coming up with new ideas; 3 ) generating varied ideas, answers, or questions; 4) developing an idea or product; 5) using creative thinking; 6) using imagination when trying to solve problems; 7) asking questions to or with friends, and 8) discussing ideas with friends and teachers. From those answers, it can be concluded that museum-based learning is considered to have an effect on both student and teacher creativity, especially in the aspect of input, insight, and inspiration leading to new ideas and solutions that students can come up with when solving a problem.

Then, several aspects occasionally mentioned are: 1) thinking of more than one answer to each problem; 2) seeing a problem from different points of view; 3) looking for many alternative solutions to problems for a problem; 4) changing approaches or other ways of thinking if one previous solution doesn't work; 4) coming up with more new and unique ideas; 5) thinking of unique ways to express oneself/ideas; 6) adding or giving details of an object or idea so that it becomes interesting; 7) adding or providing details of an object or idea so that it becomes interesting; 8) assessing and determining whether a question, a good plan, or an action is correct; 8) making decisions on various situations; 9) 
considering about the consequences of a new idea; 10) understanding that every idea has a different value for other people in society; 11) self-immersing in the creative process; 12) compiling and expressing opinions to oneself and others; 13) initiating or responding to something in the creative process appropriately; 14) understanding the rules and responsibilities during learning; 15) being able to make decisions and taking action; 16) and considering others' opinions or choosing to stick with an ideas when faced with different ideas.

Meanwhile, the aspects that are rarely mentioned by teachers are: 1) giving many suggestions for doing many things; 2) creatively making unusual combinations of parts or elements of a thing; 3 ) assessing and determining whether a question, a plan or an action is correct; 4) making decisions on various situations; 5) being dare to take risks and challenges; 6) conveying unexpected ideas; and 7) experiencing personal changes during the work process.

\subsection{Problems in Conducting Museum-Based Learning}

Although $93.3 \%$ of the respondents stated that they wanted to implement museum-based learning, they admitted that they encountered various obstacles when trying to implement it. The obstacle mentioned by almost all respondents was limited funds. As many as 24 people or $80 \%$ of respondents considered that the idea to conduct museum-based learning was not supported by sufficient funds. For public schools, funding for activities comes from one source, namely School Operational Aid (BOS) which also facilitates the overall implementation of learning in schools, so the funds should be allocated in such a way accommodating all the needs. This causes problems in the allocation of funds which is prioritized to more crucial and routine agendas. In addition, schools are not allowed to charge student parents with additional fees except tuition fees. Therefore, extracurricular activities such as museum visits only rely on funds from schools.

Another obstacle for teachers is related to administrative aspects. Teachers often find it difficult to get consent from school authorities because activities outside of school require great responsibility and security. In addition, getting permission from both schools and museums is quite complicated.

Another obstacle is related to limited facilities and infrastructure to carry out activities outside of school. Some teachers stated that the facilities and infrastructure for activities such as transportation and the availability of human resources were very limited. Some teachers stated that access to the museum was difficult and the location was far away. In fact, some teachers who came from suburban areas stated that there was no museum in their area. This shows that the implementation of museum-based learning faces the issue of infrastructure gaps among regions in Indonesia. The limited choice of museums in some areas is also an obstacle because some teachers stated that the contents of the accessible museums did not support the learning objectives that they formulized. For example, the contents of the museum are incomplete, the theme does not match the learning material and there are no museum activities that are in accordance with the learning objectives.

Moreover, intrinsic factors become the obstacles to conduct museum-based learning. Even though the teachers expressed their desire to do museum-based learning, their enthusiasm seemed to decrease when faced with the reality of the target curriculum achievement. Among the many target materials and competencies, museum-based learning is one of the activities that is considered to be finally postponed. This is closely related to the fact that there is no direct instruction for learning outside of school, especially in public schools implementing the national curriculum. As many as $56.7 \%$ of respondents stated that there was no part of the curriculum that forced them to prioritize learning outside of school, especially in museums. This is one of the main factors affecting teacher motivation in conducting museum-based learning. Other $43.3 \%$ of respondents who mostly came from private schools stated that there were instructions to have students learn at museums, but the instructions were not clearly stated in the curriculum as the museum-based learning was a program developed by the schools and teachers themselves.

\section{CONCLUSION}

Almost all respondents of this preliminary research have the intention to conduct museum-based learning. They have a positive perception of museum-based learning, as museum-based learning facilitates concrete fact-based learning, provides a new atmosphere in learning to improve student motivation, facilitates learning in and through arts, as well as serves as a means of appreciation. According to the respondents, museum-based learning positively affects both student and teacher creativity, especially the input aspects of insight and inspiration that drive new ideas and generates the variety of solutions that students can come up with when solving a problem. However, teachers still experience various obstacles in carrying out museum-based learning both in terms of funding, infrastructure, human resources, permission, supporting curricula, and availability of museums. Therefore, supports from various parties are needed to develop a curriculum that can be used by teachers in implementing museum-based learning as an effort to achieve creative pedagogy. 


\section{ACKNOWLEDGMENT}

This research is fully supported by Universitas Negeri Yogyakarta through Study Program International Collaborative Research.

\section{REFERENCES}

[1] Aaron Price, C., and A. Chiu. An experimental study of a museum-based, science PD programme's impact on teachers and their students. International Journal of Science Education 40.9 (2018): 941-960. DOI: 10.1080/09500693.2018.1457816

[2] Anderson, Lorin W., and David R. Krathwohl. Kerangka landasan untuk pembelajaran, pengajaran, dan asesmen [A fundamental framework for learning, teaching, and assessment]. Yogyakarta: Pustaka Pelajar 300.300 (2010): 0.

[3] Beghetto and James C. Kaufman. Nurturing Creativity in the Classroom 394-414. Crossref. Web. (2010) DOI: 10.1017/cbo9780511781629.020

[4] Burton, Judith M., Robert Horowitz, and Hal Abeles. Learning in and through the arts: The question of transfer. Studies in art education 41.3 (2000): 228257.

[5] Chappell, Kerry Anne, et al. Making and being made: Wise humanising creativity in interdisciplinary early years arts education. International Journal of Early Years Education 24.3 (2016): 254-278. DOI: $10.1080 / 09669760.2016 .1162704$

[6] Chappell, Kerry, and Anna Craft. Creative learning conversations: producing living dialogic spaces. Educational Research 53.3 (2011): 363-385. DOI: $\underline{10.1080 / 00131881.2011 .598663}$

[7] Chappell, Kerry. The dilemmas of teaching for creativity: Insights from expert specialist dance teachers. Thinking skills and creativity 2.1 (2007): 39-56. DOI: 10.1016/j.tsc.2007.01.001

[8] Claxton, Guy, and Bill Lucas. Educating Ruby: What our children really need to learn. Crown House Publishing, 2015.

[9] Craft, A., L. McConnon, and A. Matthews. Creativity and child-initiated play: Fostering possibility thinking in four-year-olds. Thinking Skills and Creativity 7.1 (2012): 48-61. DOI: 10.1016/j.tsc.2011.11.005

[10] Craft, Anna, and Kerry Chappell. Fostering possibility through co-researching creative movement with 7-11 year olds. (2009).

[11] Craft, Anna, Bob Jeffrey, and Mike Leibling, eds. Creativity in education. A\&C Black, 2001.

[12] Craft, Anna, et al. Creative primary schools: developing and maintaining pedagogy for creativity. Ethnography and Education 9.1 (2014): 16-34. DOI: $10.1080 / 17457823.2013 .828474$
[13] Craft, Anna. Creativity across the primary curriculum: Framing and developing practice. Routledge, 2003.

[14] Craft, Anna. Creativity and early years education: A lifewide foundation. A\&C Black, 2002.

[15] Cremin, T. Creative Teaching and Creative Teachers in Wilson. 3 rd edition) Creativity in Primary Education (2015): 33-44. DOI: 10.4135/9781473909403.n4

[16] Cremin, Teresa, Jonathan Barnes, and Stephen Scoffham. Creative Teaching for Tomorrow: Fostering a Creative State of Mind Deal. Future Creative, 2009.

[17] Cremin, Teresa, Pamela Burnard, and Anna Craft. Pedagogy and possibility thinking in the early years. Thinking skills and creativity 1.2 (2006): 108-119. DOI: 10.1016/j.tsc.2006.07.001

[18] Davies, Randall S., Douglas L. Dean, and Nick Ball. Flipping the classroom and instructional technology integration in a college-level information systems spreadsheet course. Educational Technology Research and Development 61.4 (2013): 563-580. DOI: https://doi.org/10.1007/s11423-013-9305-6

[19] Dezuanni, Michael, and Anita Jetnikoff. Creative pedagogies and the contemporary school classroom. The Routledge international handbook of creative learning (2011): 264-271. DOI: https://doi.org/10.4324/9780203817568.ch28

[20] Einarsdottir, Johanna. Principles underlying the work of Icelandic preschool teachers. European Early Childhood Education Research Journal 11.1 (2003): 3953. New

[21] Great Britain. National Advisory Committee on Creative, et al. All our futures: Creativity, culture \& education. Department for Education and Employment, 1999.

[22] Indonesia, Presiden Republik. Peraturan Pemerintah Republik Indonesia Nomor 66 Tahun 2015 Tentang Museum [Republic of Indonesia Government Regulation Number 66 of 2015 concerning Museums] (2015)

[23] Jeffrey, Bob, and Anna Craft. Creative learning and possibility thinking. Creative learning practices: European experiences (2006): 73-91.

[24] Lindström, Lars. Aesthetic learning about, in, with and through the arts: A curriculum study. International Journal of Art \& Design Education 31.2 (2012): $\quad 166-179 . \quad$ DOI: $10.1111 / \mathrm{j} .1476-$ 8070.2012.01737.x

[25] Littleton, Karen, and Neil Mercer. Interthinking: Putting talk to work. Routledge, 2013. DOI: https://doi.org/10.4324/9780203809433

[26] Marsan et al.,. The Creative Museum: Recommendations Building a Creative Museum. Creative Museum Project Partners (2017) 
[27] Mirzaie, Rasol Abdullah, Farideh Hamidi, and Ashraf Anaraki. A study on the effect of science activities on fostering creativity in preschool children. Journal of Turkish science education 6.3 (2009): 81-90.

[28] Rahm, Jrène. Project-based museum-school partnerships in support of meaningful student interestand equity-driven learning across settings. The Canadian Review of Art Education/Revue canadienne d'éducation artistique 43.1 (2016): 184-198. DOI: 10.26443/crae.v43i1.25

[29] Robinson, Ken, and Lou Aronica. Creative schools: Revolutionizing education from the ground up. Penguin UK, 2015.

[30] Sawyer, R. Keith, ed. Structure and improvisation in creative teaching. Cambridge University Press, 2011.

[31] Sawyer, R. Keith. Learning for creativity. (2010).
[32] Singapore Art Museum. Think! Contemporary: A Museum-Based School Programme That Advocates Learning through Art. Singapore Art Museum (2006)

[33] Stein, Robert. Museum Innovation: Risk, Experimentation and New Ideas. Retrieved April 3 (2013): 2013.

[34] Sternberg, Robert J. Teaching for creativity. (2010).

[35] Suhaya, Suhaya. Pendidikan Seni Sebagai Penunjang Kreatifitas [Art Education as a Support for Creativity]. JPKS (Jurnal Pendidikan dan Kajian Seni) 1.1 (2016). DOI: 10.30870/jpks.v1i1.837

[36] The Singapore Art Museum, Geylang Methodist School (Primary), Haig Girls' School, Mayflower Primary School and St. Anthony's Primary School, Ministry of Education (2016)

[37] Wibowo, Sutji Martiningsih. Pengembangan Kreatifitas [Creativity Development]. Disampaikan dalam Semiloka Guru TK. Taruna Bakti Tanggal 23 (2008). 